\title{
UJI EKSTRAK DAUN KEMANGI (Ocimum sanctum L.) DALAM BENTUK SALEP DAN SPRAY SEBAGAI SKABISIDA TUNGAU Sarcoptes scabiei
}

\author{
Ayu Tiara Fitri ${ }^{1}$, Mohammad Kanedi ${ }^{1}$, Endah Setyaningrum ${ }^{1}$, Gregorius \\ Nugroho Susanto ${ }^{1}$
}

${ }^{1}$ Jurusan Biologi, Fakultas Matematika dan Ilmu Pengetahuan Alam Universitas Lampung

[email korespondensi: Ayuuutiara@gmail.com]

\begin{abstract}
Basil Leaf Extract Test (Ocimum Sanctum L.) In The Form Of Ointments And Sprays As Scabicide Mites Sarcoptes Scabiei. The use of scabies drugs (scabicide) is generally made from synthetic chemical compounds. The effect of the administration of synthetic chemical compounds is the resistance of mites to drugs. Basil leaves can be an alternative to scabicide because they contain essential oils containing active ingredients eugenol, cineol, and flavonoids. The study was conducted in October-November 2019. The purpose of this study was to determine the potential of basil leaf extract as a scabicide and to find out the basil leaf extract preparations that were more effective between ointment and spray. This research was an experimental type with a Completely Randomized Design (CRD) consisting of four treatment groups (control + , control-, basil leaf extract ointment, basil leaf extract spray) and six replications. The research data were analyzed using One Way (ANOVA) and the results showed that there was a significant difference in the width of the scab between treatments $(p=0.000)$. The results of the study were continued using Fisher LSD (Least Significant Different) at a $5 \%$ significance level, the smallest scab width obtained in the basil leaf extract ointment preparation. The conclusion from this research is that basil leaf extract can be used as a scabicide and ointment preparations are more effective than spray.
\end{abstract}

Keywords: body mass index (BMI), diabetes melitus tipe 2, total cholesterol

\begin{abstract}
Abstrak : Uji Ekstrak Daun Kemangi (Ocimum Sanctum L.) Dalam Bentuk Salep Dan Spray Sebagai Skabisida Tungau Sarcoptes Scabiei. Penggunaan obat skabies (skabisida) umumnya terbuat dari senyawa kimia sintetik. Efek pemberian dari senyawa sintetik kimia adalah resistensinya tungau terhadap obat. Daun kemangi dapat menjadi alternatif skabisida karena memiliki kandungan minyak atsiri berbahan aktif eugenol, sineol dan flavanoid. Penelitian dilakukan pada bulan Oktober-November 2019. Tujuan dari penelitian ini untuk mengetahui potensi ekstrak daun kemangi sebagai skabisida dan untuk mengetahui sediaan ekstrak daun kemangi yang lebih efektif antara salep dan spray. Penelitian ini berjenis eksperimental dengan Rancangan Acak Lengkap (RAL) yang terdiri dari empat kelompok perlakuan (kontrol+, kontrol-, salep ekstrak daun kemangi, spray ekstrak daun kemangi) dan enam ulangan. Data hasil penelitian dianalisis menggunakan One Way (ANOVA) dan didapatkan hasil terdapat perbedaan lebar keropeng sangat bermakna pada antar perlakuan $(p=0.000)$. Hasil penelitian dilanjutkan menggunakan Fisher LSD (Least Significant Different) pada taraf nyata $5 \%$, didapatkan lebar keropeng terkecil pada sediaan salep ekstrak daun kemangi. Kesiimpulan dari penelitian ini yaitu ekstrak daun kemangi dapat digunakan sebagai skabisida dan sediaan bentuk salep lebih efektif dibandingkan bentuk spray.
\end{abstract}

Kata Kunci : ekstrak kemangi, keropeng, salep, skabies, spray 


\section{PENDAHULUAN}

Skabies merupakan salah satu jenis penyakit kulit yang banyak diderita oleh hewan dan bersifat menular. Penyakit kulit ini disebabkan oleh sekelompok tungau dari spesies Sarcoptes scabiei.

S. scabiei hidup dan berkembang biak ditubuh inang khususnya pada bagian kulit dan menyerang hampir semua jenis hewan peliharaan khususnya mamalia (seperti marmut, anjing, kucing, kelinci, kambing), tidak hanya hewan peliharaan saja yang menjadi inang tungau tersebut melainkan manusia juga rentan.

Mading dan Ira (2015) skabies dapat menular dari manusia ke manusia, manusia ke hewan bahkan dari hewan ke manusia (zoonosis). Penularan penyakit skabies dapat melalui kontak langsung maupun tidak langsung. Penularan skabies dari hewan ke manusia sangat mungkin terjadi, tidak hanya yang berada di taman kelinci saja tetapi banyak juga peternak marmut yang kurang peduli dengan kesehatan dan kondisi lingkungan marmut tersebut.

Infeksi dari penyakit kulit skabies ini kurang mendapatkan penanganan yang segera karena bersifat infeksi primer, yang berarti tanda gejala yang muncul dari adanya skabies ini tidak membahayakan jiwa tetapi apabila dibiarkan dan tidak mendapat penanganan yang benar maka akan menimbukan infeksi sekunder yang sulit untuk disembuhkan dan kulit yang terinfeksi skabies ini akan menyebar keseluruh tubuh (Golant AK, Levitt JO.2012).

Obat yang sering djual di pasaran untuk skabies dapat berupa pil, sabun, spray dan salep. Pengobatan yang sering digunakan dan banayak dijual dipasaran yaitu dari bahan dasar kimia seperti sulfadex dan permetrin. Menurut Wandel dan Rampalo dalam jurnal Mading dan Ira (2015) permetrin merupakan salah satu jenis obat skabies yang memiliki persentase kesembuhan yang tinggi sebanyak $98 \%$. Akan tetapi permetrin juga memiliki efek samping berupa rasa gatal dan sensasi menyengat pada saat penggunaannya (Currie dan McCarthy, 2010). Maka dari itu peneliti memanfaatkan obat tradisional yang berasal dari tumbuhan seperti kemangi.

Kemangi merupakan salah satu tumbuhan yang memiliki aroma yang khas. Kandungan yang terdapat didalam daun kemangi antara lain minyak atsiri yang memiliki bahan aktif berupa eugenol dan sineol yang mempunyai potensi sebagai larvasida dan juga hormon juvenil yang mampu menghambat perkembangan larva nyamuk penyebab penyakit malaria (Fatimah,1997). Selain menghambat perkembangan larva nyamuk pengebab penyakit malaria, daun kemangi juga dapat digunakan sebagai pembasmi lalat buah, kutu daun, laba-laba merah, dan tungau (Simon et al, 1990; Panhwar,2005). Daun kemangi juga memiliki potensi sebagai anti mikroba, anti inflamasi, anti oksidan dan analgesik (Moghaddam et al, 2011).

\section{METODE}

Penelitian ini dilakukan pada bulan Oktober-November 2019, dan menggunakan metode eksperimental dengan Rancangan Acak Lengakap (RAL). Yang terdiri dari 4 perlakuan yaitu kontrol +, kontrol -, salep ekstrak daun kemangi, spray ekstrak daun kemangi. Dengan masing- masing sampel sebanyak 6 keropeng.

Alat dan bahan yang digunakan dalam penelitian ini penggiling dan ayakan, pengaduk, labu ukur, rotary evaporator, neraca analitik, kertas saring, oven digunakan untuk mengeringkan daun kemangi, penggaris, pipet tetes, pipet volumetri, corong, mortar,cawan uap,botol spray, pot salep untuk menaruh salep sarung tangan latex, masker, neraca analitik, cawan petri, pipet tetes, gelas objek, kaca penutup, mikroskop, Blade, kamera, kandang marmut yang terbuat dari plastik berukuran 50 x $30 \mathrm{~cm}$, tempat makan dan minum marmut. Marmut yang berumur 3-4 bulan, pakan marmut berupa pellet atau sayur, $\mathrm{KOH} \mathrm{10 \% ,} \mathrm{daun} \mathrm{kemangi,} \mathrm{etanol}$ $96 \%$, aquadest, NaCMC, Sulfadex, 
daun kemangi, Vaseline albumin dan Cera flava.

$\begin{array}{lll}\text { 1. } & \begin{array}{l}\text { Persiapan } \\ \text { Hewan Uji } \\ \text { Sebelum }\end{array} & \text { mandang Dan } \\ & \text { melaksanakannya }\end{array}$ penelitian, disiapkan kandang untuk hewan uji berukuran $50 \times 30 \mathrm{~cm}$. Hewan yang akan digunakan pada penelitian ini mengggunakan marmut yang memiliki umur sekitar 3-4 bulan. Dengan ketentuan dilakukannya pemeriksaan laboratorium secara mikroskopis yang membuktikan bahwa marmut positif terinfeksi skabies.

\section{Pembuatan Simplisia Daun Kemangi}

Kemangi yang ada dipisahkan antara daun dan batangnya. Pada penelitian ini bagian yang digunakan hanyalah daun kemangi.Daun kemangi dibersihkan dengan air mengalir dan dipotong hingga berukuran kecil. Daun kemangi kemudian dikeringkan menggunakan oven dengan suhu 70$100^{\circ} \mathrm{C}$. Daun yang sudah kering kemudian di haluskan menggunakan blender kering setelah itu diayak untuk mendapatkan serbuk simplisia.

\section{Pembuatan Spray Ekstrak Daun Kemangi}

Memasukkan 200 gram simplisia daun kemangi dengan $2000 \mathrm{ml}$ etanol $96 \%$ kedalam wadah tertutup, diaduk hingga homogen. Kemudian didiamkan selama 1 kali 24 jam. Kemudian cairan disaring menggunakan kain saring hingga hasil yang diperoleh terbebas dari simplisia. Hasil saringan dipekatkan menggunakan alat rotary evaporator suhu $50^{\circ} \mathrm{C}$, kecepatan 60 rpm dan tekanan 120 mBar. Ekstrak kemangi yang sudah pekat dimasukkan kedalam botol spray.

\section{Pembuatan Salep Ekstrak Daun Kemangi}

Memasukkan 250 gram simplisia daun kemangi dengan $3000 \mathrm{ml}$ etanol $96 \%$ kedalam wadah tertutup, diaduk hingga homogen. Kemudian didiamkan selama 3 kali 24 jam. Kemudian cairan disaring menggunakan kain saring hingga hasil yang diperoleh terbebas dari simplisia. Simplisia yang telah disaring kemudian direndam kembali menggunakan etanol $96 \%$ sebanyak $3000 \mathrm{ml}$. Kemudian didiamkan selama
2 kali 24 jam.Kemudian cairan disaring kembali menggunakan kain saring hingga hasil yang diperoleh terbebas dari simplisia. Hasil saringan pertama dan kedua dipekatkan menggunakan alat rotary evaporator suhu $50^{\circ} \mathrm{C}$, kecepatan $60 \mathrm{rpm}$ dan tekanan 120 mBar.Kemudian cairan ekstrak daun kemangi yang pekat diletakkan dicawan uap lalu dimasukkan didalam oven pada suhu $30{ }^{\circ} \mathrm{C}$. Didiamkan selama 3 kali 24 jam hingga etanol menguap dan ekstrak menjadi pasta. Pasta ekstrak daun kemangi, Vaseline album, dan Cera flava ditimbang sesuai dengan takaran pada neraca analitik. Basis yang akan digunakan yaitu campuran antara vaselin album $45 \%$ dengan cera flava $5 \%$. Sebelum dibuat basis salep, dipanaskan terlebih dahulu lumpang dan alu di dalam oven dengan suhu $50^{\circ} \mathrm{C}$ hingga panas, kemudian lumpang dan alu yang telah panas dikeluarkan dari oven, lalu memasukkan vaselin album dan cera flava selanjutnya diaduk dengan kecepatan konstan hingga homogen dengan membentuk basis salep. Basis salep yang telah dibuat, ditambahkan dengan pasta ekstrak daun kemangi dan diaduk hingga homogen dengan menggunakan lumpang dan alu yang panas (Stiani, et al. 2015).

\section{Analisis Data}

Analisis data yang digunakan adalah (One Way) ANOVA dengan indeks kepercayaan 95\%. dan apabila terdapat beda nyata dilanjutkan dengan Fisher LSD (Least Significant Different) pada taraf nyata $5 \%$, untuk mengetahui pemberian perlakuan yang paling efektif antara perlakuan ( salep,spray, kontrol +, dan kontrol -) terhadap angka kesembuhan keropeng yang diakibatkan oleh tungau Sarcoptes scabiei. Data dianalisis menggunakan program software Minitab versi 19.

\section{Pengamatan}

Pengamatan pada keropeng dilakukan setiap hari selama 9 hari pemberian perlakuan. Pengamatan dilakukan dengan cara mengukur lebar keropeng. Tanda-tanda kesembuhan dapat dilihat dari mengecilnya lebar keropeng. Pengukuran lebar keropeng menggunakan jangka sorong. 


\section{Pemeriksaan Mikroskopis Keropeng Sebelum Diberikan Perlakuan}

Pada Gambar 4 di bawah hasil dari pengamatan mikroskopis

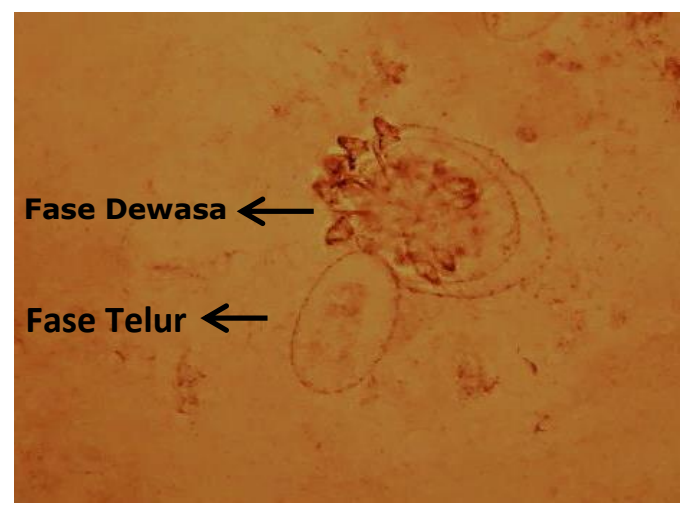

(a) menunjukkan tungau jenis $S$ scabiei pada fase telur dan dewasa.

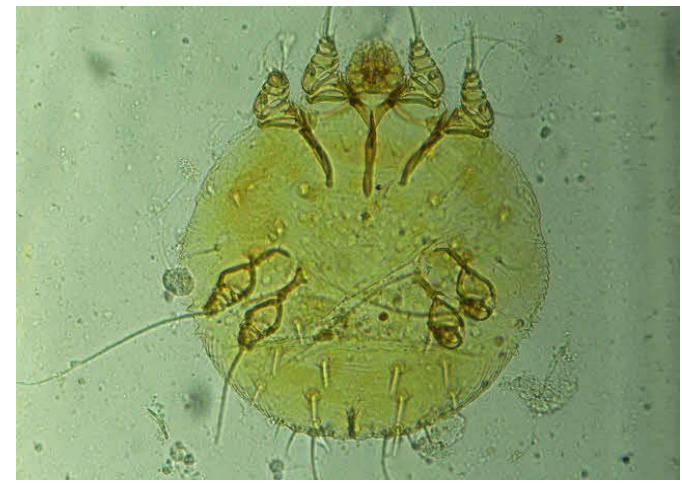

(b)

Gambar 4. Hasil pemeriksaan sampel secara mikroskopis pada kerokan kulit marmut (a. Perbesaran 100X dan b Jantan perbesaran 200X)

2. Analisis Data Yang Didapatkan

Dari Perbandingan Ekstrak

Daun Kemangi Dengan Kontrol

+ Dan Kontrol -

Penelitian tentang ekstrak daun kemangi sediaan dalam bentuk salep dan spray sebagai skabisida tungau Sarcoptes scabiei menunjukkan

terjadinya pengurangan lebar keropeng pada masing masing perlakuan kecuali pada pemberian kontrol -. Hal ini dapat dilihat pada Tabel 3 di bawah.

Tabel 3. Rerata Hasil Transformasi Lebar Keropeng Pada Marmut Yang Terinfeksi Sarcoptes scabiei Menggunakan LG10(K-X)

\begin{tabular}{llllllll}
\hline \multicolumn{7}{c}{ Rata-rata Hasil Transformasi Lebar Keropeng (mm) } \\
\hline P/U & $\mathbf{1}$ & $\mathbf{2}$ & $\mathbf{3}$ & $\mathbf{4}$ & $\mathbf{5}$ & $\mathbf{6}$ & Rata-rata \\
\hline $\mathrm{K}-($ NaCMC 5\%) & 1.08 & 1.11 & 1.2 & 1.2 & 1.15 & 1.15 & 1.15 \\
\hline $\mathrm{K}+$ (Sulfadex) & 0.6 & 0.85 & 0.18 & 0.85 & 0.48 & 0.85 & 0.63 \\
\hline $\mathrm{P} 1$ (Salep) & 0.6 & 0.18 & 0.3 & 0.3 & 0.7 & 0.6 & 0.45 \\
\hline P2 (Spray) & 0.6 & 0.78 & 0.85 & 0.85 & 0.85 & 0.6 & 0.75 \\
\hline
\end{tabular}

Keterangan : U : Ulangan; $\mathrm{P}$ : Perlakuan

Penelitian tentang ekstrak daun kemangi sediaan dalam bentuk salep dan spray sebagai skabisida tungau Sarcoptes scabiei menunjukkan terjadinya pengurangan lebar keropeng pada masing masing perlakuan kecuali pada pemberian kontrol -. Hal ini dapat dilihat pada Tabel 3 di atas.

Rata-rata lebar keropeng yang didapatkan dari semua perlakuan (kontrol-, kontrol +, salep, dan spray) di uji secara statistik menggunakan uji One Way (ANOVA) menunjukkan 
perbedaan yang sangat bermakna pada masing masing perlakuan yaitu $p<5 \%$.

Hal ini dapat dilihat pada Tabel $4 \mathrm{di}$

Tabel 4. Data Hasil Uji One Way ANOVA

\begin{tabular}{lccccc}
\hline Sumber Variasi & db & JK & MK & F-Value & P-Value \\
\hline Faktor & 3 & 1.5864 & 0.52879 & 15.67 & 0.000 \\
\hline Error & 20 & 0.6747 & 0.03374 & & \\
\hline Total & 23 & 2.2611 & & & \\
\hline Keterangan : db & $:$ : Derajat Bebas & & & \\
& JK & $:$ Jumlah Kuadrat & & & \\
& MK & : Rata-rata Kuadrat & & &
\end{tabular}

Dikarenakan pada uji One Way Anova pada Tabel 4 di atas menunjukkan nilai $p=0.000$ maka dilanjutkan dengan uji lanjut menggunakan Fisher LSD (Least Significant Different) didapatkan hasil Salep tidak memiliki beda nyata terhadap kontrol + tetapi memiliki beda nyata pada perlakuan spray dan kontrol-. Menandakan bahwa ekstrak daun kemangi jenis sediaan dalam bentuk salep memiliki kemampuan mengobati skabies sama seperti obat yang sering dijual. Sedangkan kontrol + tidak memiliki beda nyata terhadap pemberian perlakuan salep dan spray, tetapi memiliki beda nyata terhadap kontrol -. Dan untuk kontrol didapatkan beda nyata tehadap pemberian perlakuan kontrol + , salep, dan spray. Hal ini dapat dilihat pada Tabel 5.

Tabel 5. Rerata Lebar Keropeng Pada Uji Lanjut Fisher LSD Marmut Yang Terinfeksi S.Scabiei

\begin{tabular}{ll}
\hline Perlakuan & $\begin{array}{l}\text { Rerata Lebar Keropeng (Mean } \pm \\
\text { Std. Deviasi) }(\mathbf{m m})\end{array}$ \\
\hline $\mathrm{K}-($ NaCMC $5 \%)$ & $1.1489 \pm 0.049^{\mathrm{a}}$ \\
\hline $\mathrm{K}+($ Sulfadex $)$ & $0.632 \pm 0.270^{\mathrm{bc}}$ \\
\hline $\mathrm{P} 1$ (Salep ekstrak daun kemangi) & $0.4475 \pm 0.2124^{\mathrm{c}}$ \\
\hline $\mathrm{P} 2$ (Spray ekstrak daun kemangi) & $0.7529^{ \pm} \pm .1197^{\mathrm{b}}$ \\
\hline
\end{tabular}

Keterangan :

Angka yang diikuti dengan huruf

Superskrip yang berbeda menunjukkan

beda nyata dengan uji Fisher LSD (Least

significant Different) taraf $5 \%$.

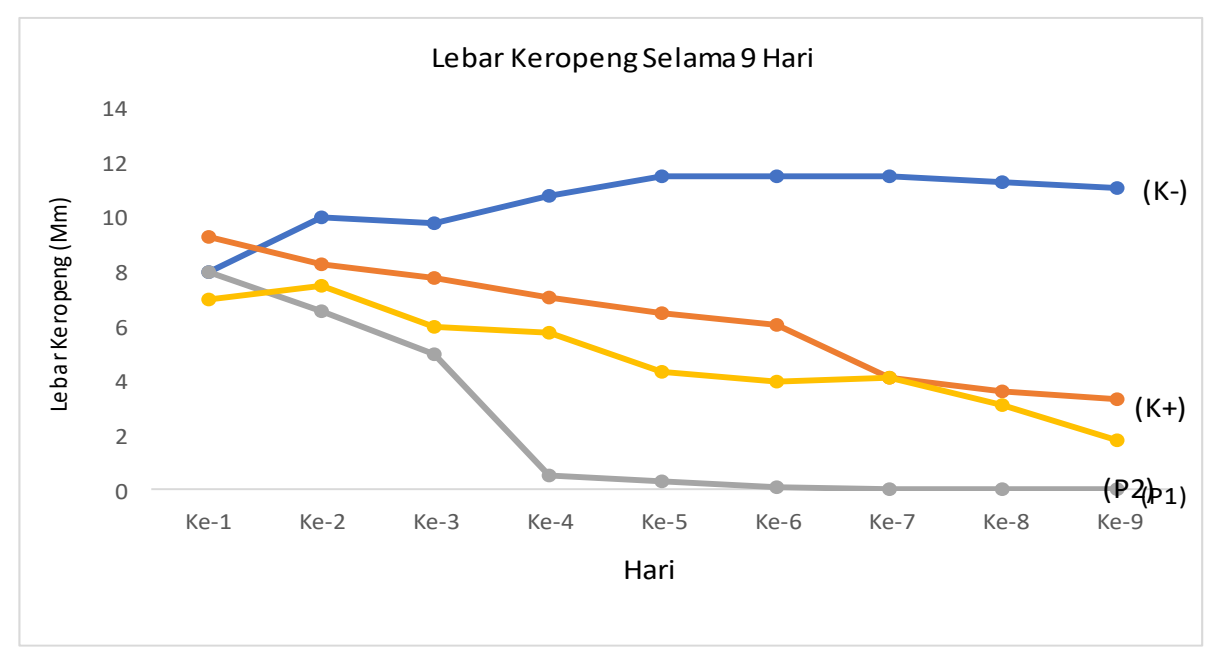

Gambar 5. Grafik Rerata Lebar Keropeng Selama 9 Hari. 
Keterangan : K- : Kontrol Negatif (NaCMC 5\%) P1: Salep ekstrak daun kemangi $\mathrm{K}+$ : Kontrol Positif (Sulfadex) P2: Spray ekstrak daun kemangi

Pemberian perlakuan menggunakan jenis sediaan dalam bentuk salep ekstrak daun kemangi memiliki kemampuan menyembuhkan keropeng lebih cepat dibandingkan dengan pemberian perlakuan seperti kontrol + dan sediaan dalam bentuk spray. Hal ini dapat dilihat pada Gambar 5.

3. Perbandingan

Keropeng

Berdasarkan hasil penelitian ini perbandingan sebelum dan sesudah diberikannya NaCMC 5\%, Suldex, Salep ekstrak daun kemangi, dan Spray ekstrak daun kemangi sangat terlihat pada Tabel 6 pada jenis perlakuan obat skabies, dan ekstrak daun kemangi sediaan dalam bentuk salep dan spray. Keropeng yang telah diberi perlakuan yaitu kontrol+, salep dan spray, mengalami kesembuhan yang terlihat perbedaannya, sedangkan untuk kontrol- keropeng tidak menunjukkan tanda tanda kesembuhan cenderung bertambah parah.

\section{Tabel 6. Perbandingan Kondisi Keropeng Sebelum Dan Sesudah} Dilakukannya Pemberian Perlakuan.

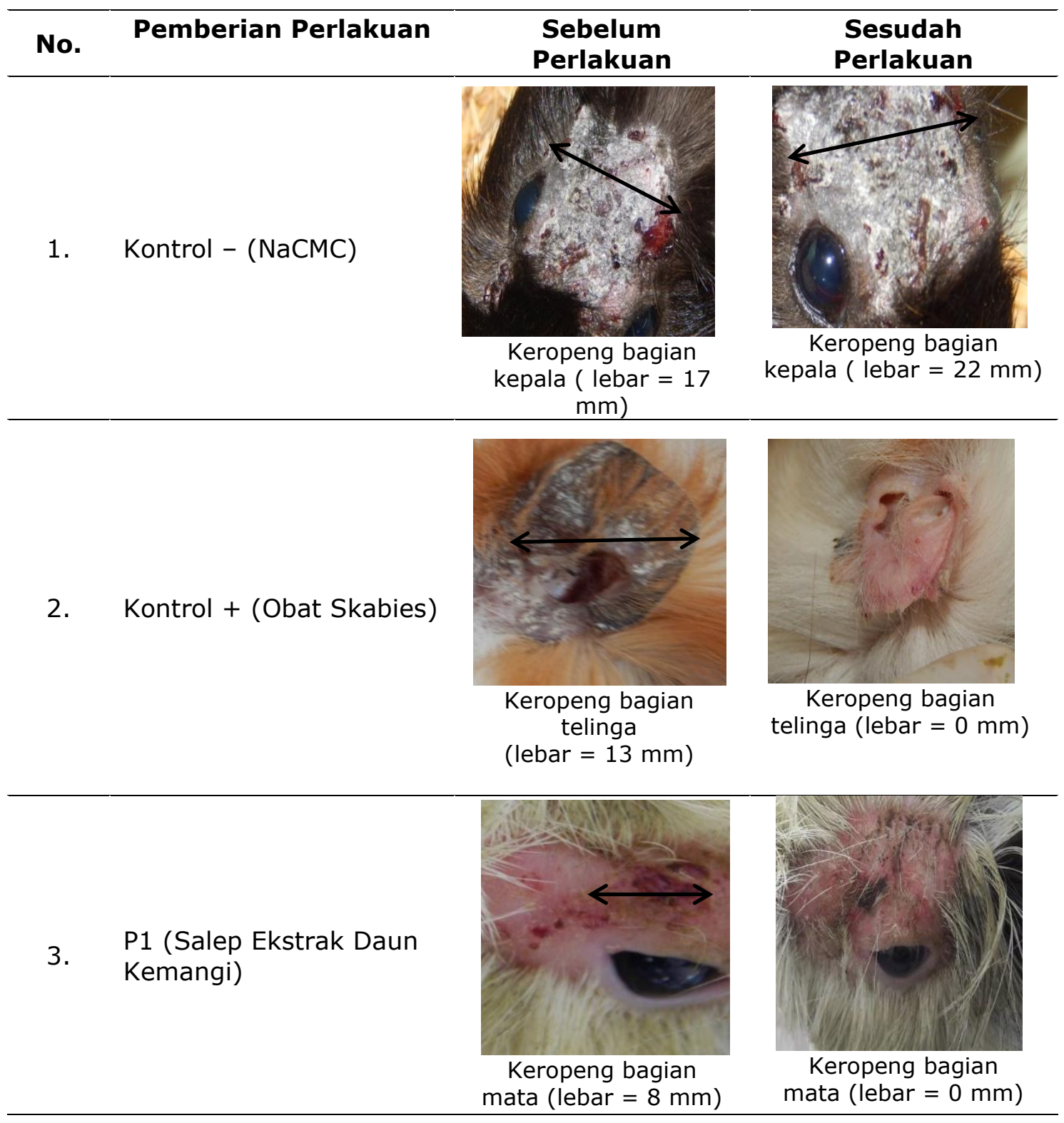


4.

P2 (Spray Ekstrak Daun Kemangi)

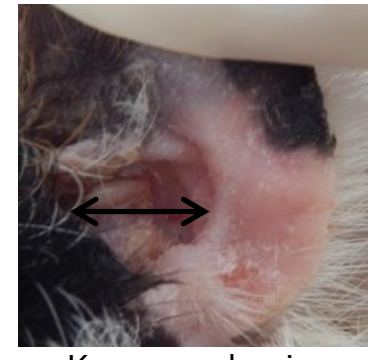

Keropeng bagian telinga (lebar $=7 \mathrm{~mm}$ )

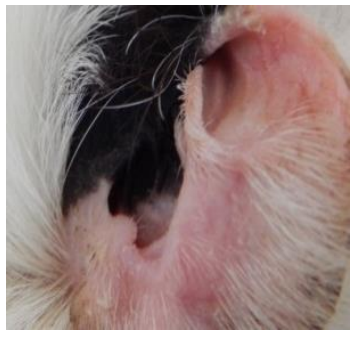

Keropeng bagian telinga (lebar $=0 \mathrm{~mm})$

\section{PEMBAHASAN}

Penelitian tentang ekstrak daun kemangi sediaan salep dan spray pada Gambar 4 di atas, dari hasil pemeriksaan secara mikroskopis sampel keropeng marmut yang terkena skabies menunjukkan hasil positif yaitu adanya tungau S. scabiei pada sampel keropeng. Hal tersebut sesuai dengan pendapat Colville and Joanna, (2002) yaitu penyakit skabies yang sering terjadi pada kambing, domba, sapi, kelinci, dan marmut disebabkan oleh tungau jenis $S$. scabiei. Pada penelitian ini juga ditemukan tungau S. scabiei dalam beberapa fase yaitu fase telur dan fase dewasa.Pemberian perlakuan menggunakan ekstrak kemangi dalam bentuk salep maupun spray memiliki kesamaan yaitu menunjukkan pengurangan terhadap lebar keropeng, dapat dilihat dari rata-rata data pada Tabel 3 dan Gambar 5 di atas. Hal ini juga membuktikan bahwa ekstrak daun kemangi dapat digunakan sebagai skabisida. Daun kemangi memiliki kandungan berupa minyak atsiri yang memiliki bahan aktif eugenol dan sineol memiliki potensi sebagai skabisida, sedangkan untuk hormon juvenil dapat menghambat perkembangan larva nyamuk (Anopheles aconitus) (Octavia, et al, 2008).

Senyawa bioaktif yang diduga berfungsi sebagai larvasida dari kemangi ini adalah eugenol dan methyl clavical (Iffah et.al, 2008). Kandungan senyawa flavanoid pada kemangi ini dapat mengurangi rasa sakit, meningkatkan sistem imun, dan membantu proses penyembuhan luka (Naibaho, et.al, 2013).
Sedangkan untuk mekanisme daun kemangi terhadap tungau itu sendiri adalah dengan cara daun kemangi sebagai racun kontak melalui permukaan tubuh larva. Hal ini disebabkan kandungan senyawa minyak atsiri aktif berupa fenol atau eugeol mudah terserap melalui kulit (Wilbraham dan Matta, 1992). Prinsip kerja senyawa fenol dapat menyebabkan cacat bakar dan amat beracun (Wilbraham dan Matta, 1992). Eugenol merupakan senyawa fenol yang memiliki gugus alkohol sehingga dapat melemahkan dan mengganggu sistem syaraf tungau (Iffah et.al, 2008).

Senyawa aktif lainnya yaitu methyl clavical yang termasuk kedalam kelompok ether. Senyawa methyl clavical juga memiliki efek anastetikum. Seperti halnya contoh kelompok ether yang lain, diperkirakan methyl clavical bekerja dengan cara mengganggu kerja susunan syaraf tungau. Semakin tinggi ekstrak daun kemangi yang digunakan maka semakin tinggi zat bioaktif didalam kemangi yang bekerja mempengaruhi proses rontoknya kutikula dari tungau (Wilbraham \& Matta, 1992); (Iffah et.al, 2008).

Menurut Isman (2000), Dubey et al. (2008); Koul et al. (2008); dan Dubey et al. (2010), aktivitas biologi minyak atsiri terhadap serangga dapat bersifat mengurangi nafsu makan (antifeedant), menolak (repellent), menurunkan fertilitas, menarik (attractant), racun kontak (toxic), menghambat peletakan telur (ovipotion deterrent), racun pernafasan (fumigant), menghambat 
pertumbuhan, serta sebagai anti serangga vektor (Hartati, 2012).

Pemberian perlakuan dan pengamatan yang dilakukan selama 9 hari, didapatkan hasil yang menunjukkan pengurangan lebar keropeng yang paling cepat yaitu menggunakan perlakuan sediaan dalam bentuk salep dibandingkan dengan sediaan dalam bentuk spray, dapat dilihat diatas pada Gambar 5 grafik yaitu pada pemberian sediaan salep pada hari ke tujuh menunjukkan keropeng telah hilang yang diakibatkan oleh tungau S.scabiei.

$\mathrm{Hal}$ ini sesuai dengan pendapat Stiani, 2015, Sediaan dalam bentuk salep dengan campuran ekstrak etanol daun kemangi, Cera flava, Vaseline album termasuk salep dengan basis hidrokarbon yang memiliki daya sebar yang luas, dan memiliki daya lekat yang sangat kuat, sedangkan untuk kemampuan proteksi salep dengan basis hidrokarbon ini memiliki kemampuan untuk melindungi kulit dari pengaruh luar (Stiani,2015).

Pada Tabel 3 dan Tabel 5 menunjukkan bahwa kontrol negatif menggunakan NaCMC 5\% memiliki nilai rata-rata lebar keropeng yang paling tinggi yaitu $1.1489 \mathrm{~mm}$ dan jika dilihat pada Tabel 6 Perbedaan keropeng sebelum dan sesudah diberi perlakuan tidak memiliki beda dan cenderung melebar lebar keropeng. Hal ini dikarenakan NaCMC memiliki sifat sebagai stabilisator, sebagai pengental, pembentuk gel dan sebagai pengemulsi. Na-CMC tidak berfungsi sebagai pengemulsi tetapi lebih sebagai senyawa yang memberikan kestabilan (Fardiaz, et.al,1987).

Sedangkan pada pemberian perlakuan kontrol + menggunakan obat skabies berupa sulfadex dapat dilihat pada Tabel 3 dan Tabel 5 mendapatkan nilai rata-rata lebar keropeng sebesar $0.632 \mathrm{~mm}$. Hal ini dikarenakan sulfadex merupakan salah satu jenis obat skabies yang banyak dijual, pengaplikasian obat skabies ini adalah dengan cara disemprotkan. Sedangkan untuk kandungan aktif pada sulfadex itu sendiri terdiri atas sulfadiazine, povidone iodine, zink bacitracin, neomison sulfat dan ciflutrin (Risyani, 2017). Pada Tabel 6 keropeng yang belum diberi perlakuan memiliki kondisi kulit yang berkerut dan mengalami kebotakan pada bagian yang terdapat keropeng. Hal ini dikarenakan penyakit skabies akan menghasilkan eksudat yang akan menyerap keluar kulit kemudian mengering membentuk keropeng pada permukaan kulit. Keropeng lama kelamaan akan menebal dan selanjutnya terjadi keratinasi serta proliferasi pada jaringan ikat (Subroto,2008).

Tabel 6 di atas menunjukkan sebagaian besar tubuh marmut yang terinfeksi tungau S.scabiei yaitu pada bagian telinga, kepala, hidung, mata, dan kaki. Hal ini serupa menurut Supriyanto dan luviana, (2010) yang menyatakan skabies biasa menyerang tubuh hewan pada bagian kepala, telinga dan kaki. Pada tahap awal gejala penyakit skabies ditandai dengan kulit yang mengalami peradangan, hal ini dapat terjadi karena tungau S.scabiei mulai menembus lapisan epidermis dan menyebabkan luka ( Hadi,2010).

\section{KESIMPULAN}

Ekstrak daun kemangi berpotensi sebagai skabisida dan sediaan dalam bentuk salep lebih efektif dibandingkan dengan spray dalam menyembukan penyakit skabies pada marmot.

\section{SARAN}

Disarankan untuk penelitian selanjutnya untuk dapat meneliti dosis dan konsentrasi yang sesuai juga mengamati parameter lainnya, seperti perhitungan jumlah tungau Sarcoptes scabiei banyaknya rambut yang tumbuh.

\section{DAFTAR PUSTAKA}

Colville, T and M.B. Joanna. 2002. Clinical Anatomy and Physiology for Veterinary Technicians. Mosby Elsevier. St. Louis Missouri.

Currie B.J. dan McCarthy J.S., 2010. Permethrin and Ivermectin for Scabies. The New England Journal of Medicine, 362: 717 -725.

Fatimah S. 1997. Studi Laboratorium Uji Kepekaan Larva Anopheles 
aconitus terhadap Ekstrak Ocimum basilicum. UNDIP. Semarang.Skripsi.

Fardiaz, Srikandi, R.Dewanti, S.Budijanto. 1987. Risalah Seminar ; Bahan Tambahan Kimiawi (FoodAdditive). Institut Pertanian Bogor, Bogor

Golant AK, dan Levitt JO. 2012. Scabies: a review of diagnosis and management based on mite biology.Pediatric Rev.2012;33;e1e12.

Hadi,U.K. 2010. Scabies in Indonesia.J. Faculty Of Veterinary Medicine

Iffah, D., Gunandini, D. J., \& Kardinan, A. 2008. Pengaruh Ekstrak Kemangi (Ocimum basilicum forma citratum) terhadap Perkembangan Lalat Rumah (Musca domestica) (L.). Jurnal Entomologi, 5(1), 36-44.

Mading,M., dan I. Indriaty P.B.S.2015. Kajian Aspek Epidemiologi skabies pada manusia. Jurnal Penyakit Bersumber Binatang Vol. 2 No.2.

Moghaddam A, Syayegh J. Mikaili P. Syaraf. 2011. Antimicrobial activity of essential oil extract of Ociu basilicum in leaves on a variety of pathogenic bacteria. Journal of Medicinal Plants Research 5(15):3454

Naibaho O. Paulina V. Yamlean W. W.2013. Effect of ointment base on the formulation of ointment of basil leaf extract (Ocimum sanctum L) on rabbit skin bark made by Staphylococcus aureus. Pharmaceutical Scientific Journal; 2 ( 2) 28.

Octavia, D., Andriani, S., Qirom, M., \& Azwar, F. 2008. Keanekaragaman Jenis Tumbuhan Sebagai Pestisida Alami Di Savana Bekol Taman Nasional Baluran. Jurnal Penelitian Hutan dan Konservasi Alam, Vol. 5 No. 4.

Panhwar, F., 2005. Genetically evolved of guava (Psidium gaajava) and its future in Pakistan. Virtual Lybrary Chemistry.

Risyani,R., 2017. Uji Aktivitas Ekstrak Daun Sirsak (Annona nuricata L.)Secara IN VIVO Terhadap Scabies Pada Kambing Kacang (Capra hircus). Fakultas
Kedokteran. Progrram Studi Kedokteran Hewan. Universitas Hasanuddin.Skripsi.

Simon,J.E.,J.Quinn., dan Murray.R.G., 1990. Basil : A Source of essensial oil.in J. Janick and J.E.Simon (Eds), Advances New Crops, Timber Press.Portland,OR.

Stiani,S.N.,R. Rumantir, S. Megawati. 2015. Formulasi Salep Ekstrak Etanol Daun kemangi (Ocimum Basilium L.)Sebagai Antifungi Dengan Variasi Tipe Basis Salep Dan Evaluasi Sifat Fisiknya. Jurnal Farmagazine, Vol 2 No.1.

Subronto. 2008. Ilmu Penyakit Ternak I-b (Mamalia). Gadjah Mada University. Press. Yogyakarta. 